\title{
KORELASI PERSEPSI TENTANG EFEK SAMPING KEMOTERAPI DENGAN KUALITAS HIDUP PASIEN KANKER PAYUDARA
}

\author{
Shanti Lesmana Sari, Rani Lisa Indra, Raja Fitriana Lestari \\ Program Studi Keperawatan STIKes Hangtuah Pekanbaru \\ ${ }^{*}$ Correspondence: shanti.shari26@gmail.com
}

Dikirimkan 1 Juli 2019; Diterima 3 Juli 2019; Dipublikasikan Agustus 2019

\begin{abstract}
Chemotheraphy treatments undergone by breast cancer patient's have several side effect. From the side effects that, each patient perceives the side effects that will interfere their daily lives which in turn affect the quality of life. This research was made for khowing the correlation of chemotheraphy's side effect with quality of life of breast cancer patient's in Arifin Achmad Hospital in Riau Province. The research was one of quantirative correlation research with cross-section method that had been done to 63 respondents in Arifin Achmad Hospital in Riau Province by using consecutive sampling technique bye used was questionnaire. Test used unpaires $t$ test. This research result was gotten if Pvalue=0.216 (Pvalue=0.05), which mean is no correlation between chemotheraphy's side effect perspective and quality of life of breast cancer patient's. Based on the result, we hope Arifin Achmad Hospital in Riau Province develop more health service to the community to increase positive judgement from chemotheraphy treatment and quality of life of breast cancer patient's.
\end{abstract}

Keywords : Breast Cancer, Perception, Quality of Life.

\section{PENDAHULUAN}

Kanker payudara adalah pertumbuhan sel-sel yang tidak terkendali dari pertumbuhan normalnya yang bisa tumbuh pada kelenjar susu, saluran susu, jaringan lemak dan jaringan ikat yang terdapat pada payudara tetapi tidak pada kulit payudaranya. Biasanya terdapat di kuadran kanan atas bagian luar payudara dan berbentuk benjolan yang keras, tidak beraturan dan dapat digerakkan(1). Insiden terjadinya kanker payudara ini semakin tahun semakin meningkat angkanya berhubung dengan faktor risiko seperti penggunaan kontrasepsi dan penggunaan silikon payudara, dan gaya hidup yang kurang sehat, seperti kurangnya konsumsi sayuran dan buahan, mengkonsumsi alkohol dan kurangnya aktivitas olahraga(2). Berdasarkan laporan Globocan International Agency for Reseacrh on Cancer pada tahun 2018, jumlah insiden kanker payudara di dunia mencapai angka 2.088.849 orang dan angka kematian 626.679 orang. Data dari rekam medis RSUD Arifin Achmad Provinsi Riau Januari tahun 2017, ditemukan data orang-orang dengan diagnosis kanker payudara mencapai 2.810 orang dengan angka kematian 59 orang. Kanker payudara ini banyak terjadi pada usia 45-65 tahun dengan kejadian sebanyak 1.625 orang(3). Kemudian meningkat pada tahun 2018 mencapai angka 2970 orang dengan angka kematian 86 orang dengan kejadian terbanyak pada umur 45-65 tahun yaitu sebanyak 1675 orang(4). Pasien kanker payudara di Indonesia hampir 50\% wanita datang dengan stadium akhir baru menyadari sehingga sulit untuk diobati serta terlambatnya dan terbatasnya penatalaksanaan yang akan dilakukan. Akibat dari keterlambatan penatalaksanaan kanker payudara ini akan mengalami komplikasi atau bermetastasis pada jaringan organ lainnya, seperti bermestasis ke kelenjar getah bening supraklavikula dan servikal, bermetastasis ke tulang, dan fungsi hati abnormal(1). Penatalaksanaan kanker payudara ini ada beberapa cara seperti operasi, terapi radiasi, terapi hormonal, dan kemoterapi. Salah satu pengobatan yang paling sering dilakukan adalah kemoterapi. Kemoterapi merupakan suatu proses pengobatan dengan memberikan obatobatan anti kanker yang berbentuk cairan, kapsul atau bisa melalui cairan infus 
yang berguna untuk membunuh sel kanker, tetapi juga bisa membunuh selsel yang baik diseluruh tubuh(5).

Kemoterapi juga bisa bersifat terapi utama apabila keadaaan kanker payudara sudah menyebar dan tidak bisa dilakukan operasi lagi(2). Data yang didapatkan di ruangan Seruni di RSUD Arifin Achmad pada tahun 2018 didapatkan sebanyak 1696 pasien kanker payudara yang menjalankan kemoterapi. Kemoterapi terbagi menjadi tiga macam yaitu adjuvant, neoadjuvant dan primer (paliatif). Kemoterapi adjuvant adalah terapi awal dengan pembedahan atau terapi radiasi. Obat yang digunakan bertujuan untuk mengeliminasi sisa-sisa kanker ssubmikroskopis yang dicurigaai sel kanker masih ada. Kemoterapi neoadjuvant adalah terapi yang dilakukan sebelum operasi pada stadium lanjut dengan tujuan untuk mengurangi atau memperkecil derajat kanker dan bisa menjadikan sel kanker itu bisa dibedah atau bahkaan disembuhkan dengan lanjutan terapi lokal. Kemoterapi primer (paliatif) adalah terapi yang diberikan pada stadium IV, untuk mempertahankan kualitas hidup yang baik, persentase untuk diobati kecil, dan gunakan untuk hanya mengontrol gejalanya(6).

Kemoterapi yang dilakukan bertujuan untuk membunuh sel kanker tetapi memiliki efek samping pada sel normal dalam tubuh. Secara umum efek samping yang ditimbulkan oleh pengobatan kemoterapi berupa fisik dan non fisik (psikologis). dari segi fisik dapat terjadi gangguan pada sumsum tulang belakang, gangguan saluran cerna (anoreksia), bersifat toksik pada organ lain (seperti jantung, hati, dan ginjal), rambut rontok hingga mengalami alopesia karena penggunaan obat-obatan yang diberikan. Pasien juga mengalami gangguan kulit, mulut, dan tenggorokan seperti kulit tampak kering dan membiru(2). Sedangkan dari non fisik (psikologis) yaitu harga diri pasien terganggu, kesejahteraan pasien terganggu, seksualitas terganggu, dan stress tentang diagnosis yang secara pontesial yang mengancam jiwa(7)

Hasil penelitian yang dilakukan oleh Aslam et al (2014) tentang efek samping kemoterapi pada pasien yang dilakukan pada 100 pasien kanker secara umum mengalami efek samping kemoterapi melaporkan keluhan kelemahan 95\%, kelelahan 90\%, mual 77\%, rambut rontok 76\% dan muntah $75 \%$. Sedangkan pada data penelitian yang dillakukan Indriyatmo (2015) tentang hubungan dukungan keluarga dengan motivasi pasien kanker payudara yang menjalani kemoterapi di ruangan One Day Care RSUD Dr. Moewardi melakukan wawancara yang dilakukan pada 10 pasien kanker yang mengalami kemoterapi didapatkan data pasien yang mengalami diare 33,0\%, pasien yang mengalami nyeri kejang dan kembung 67,0\%, pasien yang mengalami nyeri pinggang bagian bawah dan feses bercampur darah $54,4 \%$.

Penelitian yang dilakukan Gurung dan Pandey pada tahun 2015 tentang persepsi tentang efek samping kemoterapi pada pasien kanker di Nepal, mengemukan bahwa efek samping dikelompokkan dalam segi fisik dan segi non fisik. Segi fisik pasien mengalami efek samping seperti sakit kepala ringan, mual muntah, cepat merasa lelah, kerontokan rambut, serta perasaan mati rasa pada kaki dan tangan. Sedangkan pada segi non fisik (psikologis) pasien mengalami gangguan dalam berhubungan dengan keluarga terutama pada pasangan, kecemasan kehilangan perkerjaan, hubungan sosial terganggu, kecemasan, serta merasakan teru-menerus kelelahan. Dari efek samping psikologis ini bisa menganggu kualitas hidup pasien kanker payudara terganggu(8). Penelitian lain yang dikemukan oleh Faisel pada tahun 2015 tentang Gambaran efek samping kemoterapi berbasis antasiklin pada kanker payudara di RSUD Dokter Soedarso Pontianak di dapatkan dari 51 pasien kanker payudara, didapatkan efek samping yang tersering yaitu alopesia $94,1 \%$, mual $84,3 \%$, muntah $58,8 \%$, myalgia $39,2 \%$, neuropati $31,4 \%$, rentan terinfeksi $25,5 \%$, stomatitis $23,5 \%$, diare $19,6 \%$, dan yang paling jarang terjadi yaitu trombositopenia 13,7\%(9). Dari beberapa efek samping diatas dapat disimpulkan bahwa efek samping yang alami oleh setiap pasien berbeda-beda, sebagian pasien yang sudah menjalani kemoterapi menilai bahwa efek sampingnya itu biasa aja dan akan hilang sendiri, tetapi pada sebagian pasien lainnya menilai itu menganggu pada fisik dan psikologisnya terutama dalam melakukan kegiatan sehari-hari(10). 
Persepsi merupakan pengalaman yang dihasilkan oleh alat indra bagian penglihatan, pendengaran, penciuman, dan sebagainya. Setiap individu memiliki persepsi yang berbeda terhadap objek yang sama(11). Menurut Walgito (2010), persepsi selalu ada dalam diri individu, pikiran, perasaan, pengalaman-pengalaman individu akan ikut aktif berpengaruh serta cara individu melihat situasi sering kali lebih penting dari pada situasi itu sendiri. Persepsi atau penilaian dari masingmasing pasien mengenai efek samping yang dialami berbeda-beda dan menimbulkan gangguan pada kehidupan sehari-hari dan kualitas hidupnya (8).

Kualitas hidup adalah pandangan seseorang terhadap kesejahteraan fisiologis dalam proses peran dan fungsi fisik serta keadaan tubuh yang berpengaruh pada kesehatan umum, dan kesejahteraan mental dalam proses peran emosi dan sosial. Pada setiap individu kualitas hidup berbeda-beda tergantung dengan keterbatasan diri yang bersifat fisik, kognitif, mental, emosional dan penyakit kronis lainnya (12). Pada pasien kanker payudara, kualitas hidup menjadi isu dalam proses pengobatan dan pemulihan. Studi psikososial terdahulu menekankan bahwa adaptasi terhadap kehilangan payudara merupakan salah satu faktor penting bagi wanita, terutama pada badaya barat. Pada pasien kanker payudara cenderung mengkhawatirkan posisi dan perkerjaan menjadi terganggu, dan fungsi dalam keluarga berubah secara signifikan(7). Menurut hasil penelitian tentang gambaran kualitas hidup pasien kanker payudara di Rumah Sakit Umum Bahteramas Provinsi Sulawesi Tenggara, didapatkan bahwa hasil penelitian menemukan perasaan positif yang dirasakan oleh penderita kanker payudara antara lain perasaan sabar, optimis dan perasaan damai, keadaan kognisi penderita kanker payudara berupa kemampuan berpikir logis, mengingat dan berkonsentrasi penderita tergolong baik, komponen dari harga diri antara lain kepercayaan diri dan harapan, komponen dari gambaran diri antara lain perubahan dan kepuasan bentuk tubuh, serta perasaan negatif yang dirasakan oleh penderita antara lain cemas, sedih dan takut(13). Sedangkan hasil penelitian Rochmawati (2015) kualitas hidup pada pasien cancer mamae yang menjalani kemoterapi didapatkan bahwa menggangu kualitas hidup karena efek samping kemoterapi yang telah dijalaninya terutama dalam aspek fisik, psikologis, dan lingkungan(14).

Survei awal yang dilakukan pada 10 pasien kanker payudara di ruangan Seruni RSUD Arifin Achmad Provinsi Riau. Pada 3 orang pasien mengatakan bahwa penilaian terhadap efek samping kemoterapi positif karena setelah mereka melakukan kemoterapi yang dirasakan badan terasa segar dan lebih termotivasi melakukan kemoterapi. Namun, pada 7 orang pasien mengatakan bahwa penilaian terhadap efek samping samping kemoterapi adalah negatif karena pasien setelah melakukan kemoterapi mengalami mual muntah, kehilangan nafsu makan serta mengganggu aktivitas fisik dalam kehidupan pasien sehari-hari. Dilihat fenomena diatas, maka peneliti tertarik untuk melakukan penelitian tentang "Hubungan Persepsi tentang Efek Samping Kemoterapi dengan Kualitas Hidup Pasien Kanker Payudara di RSUD Arifin Achmad Provinsi Riau”.

\section{METODE PENELITIAN}

Jenis penelitian kuantitatif korelasi dengan desain yang digunakan Cross Sectional. Populasi pada penelitian ini yaitu pasien kanker payudara yang menjalani kemoterapi yang berjumlah 200 responden. Jumlah sampel 63 orang. Jenis teknik sampling yang digunakan pada penelitian ini teknik Consecutive Sampling. Instrumen penelitian yang digunakan adalah Angket/kuesioner. Peneliti kemudian melakukan pengolahan data melalui program komputer. Peneliti menganalisis data yang meliputi analisa univariat dan bivariat dengan uji Kolmogorov smirnov untuk uji normalitas. Jika datanya normal maka dilakukan uji t tidak berpasangan dengan nilai p>0,05, tetapi jika datanya tidak normal maka menggunakan uji alternatif yaitu uji Mann Whitney.

\section{HASIL DAN PEMBAHASAN}

Hasil penelitian yang dilakukan dari bulan Mei-July 2019 pada 63 responden pasien kanker payudara di RSUD Arifin Achmad Provinsi Riau, dengan data yang diperoleh sebagai berikut 
ini:

Gambaran karakteristik responden dapat dilihat seperti pada tabel 1 berikut ini:

Tabel 1. Distribusi Frekuensi Karakteristik Responden Berdasarkan Umur Pasien Kanker Payudara

\begin{tabular}{ccc}
\hline Umur & f & $\%$ \\
\hline $\begin{array}{c}\text { 25-35 tahun } \\
\text { (dewasa awal) }\end{array}$ & 20 & $31.7 \%$ \\
\hline $\begin{array}{c}\text { 36-45 tahun } \\
\text { (dewasa akhir) }\end{array}$ & 31 & $19.0 \%$ \\
\hline $\begin{array}{c}\text { 46-55 tahun } \\
\text { (lansia) }\end{array}$ & 12 & $49.2 \%$ \\
\hline
\end{tabular}

Berdasarkan Tabel 1 diatas dapat diketahui bahwa dari 63 responden yang diteliti, distribusi frekuensi umur responden mayoritas didapatkan dalam rentang umur 36-45 tahun (dewasa akhir) sebanyak 31 orang (49.2\%). Menurut Price dan Wilson (2006), wanita yang berumur 30 tahun keatas mempunyai kemungkinan lebih besar untuk terkena kanker payudara ini. Sesuai dengan penelitian usia mempunyai hubungan yang signifikan dengan kejadian kanker payudara. Pada kelompok umur dewasa akhir mempunyai resiko terkena kanker payudara sebesar 1,4 kali dan dibandingkan dengan umur $>55$ tahun keatas. Hal ini mungkin dikaitkan dengan kejadian kanker payudara pada usia 36-45 tahun, dikarenakan sebagian besar berumur 35-45 tahun atau disebut dengan rentang usia akhir, pada rentang usia ini pengaruh hormon estrogen ini semakin besar dan lebih produktif lagi, disertai pengaruh gaya hidup yang tidak sehat dan kurang konsumsi sayuran menjadi faktor resiko terjadinya kanker payudara(15).

Tabel 2. Tendency Central Berdasarkan stadium kanker payudara dan siklus kemoterapi

\begin{tabular}{lcll}
\hline & mean & SD & Min-Maks \\
\hline Stadium & 2,05 & 0,58 & $1-3$ \\
\hline Siklus & 6.33 & 3.00 & $1-14$ \\
\hline
\end{tabular}

Berdasarkan Tabel 2 diatas dapat kita ketahui bahwa pasien kanker payudara di RSUD Arifin Achmad Provinsi Riau yang menjadi responden adalah pasien kanker payudara pada stadium 2 dengan standar deviasi o.580. Menurut Olfah, Mendri dan Badi'ah pada tahun 2013 juga menyatakan bahwa pasien kanker payudara hampir 50\% datang dengan stadium akhir, sehingga menyebabkan keterbatasan penanganan yang akan dilakukan(1). Penelitian Wahyudi, Huda dan Utami (2015) didapatkan bahwa penderita kanker payudara terbanyak pada stadium 3 dengan nilai 43,4\%(10). Kemudian sejalan dengan penelitian yang dilakukan oleh Nugraha dan Melati pada tahun 2016 didapatkan juga stadium penderita kanker payudara yang terbanyak adalah stadium 3 dengan nilai $33,3 \%$. Pada stadium 2 ini terdapat pilihan dalam penanganannya kanker payudara yaitu operasi dan kemoterapi, karena stadium 2 ini keadaan sel kanker lebih dari $2 \mathrm{~cm}$ dan telah bermetastasis ke kelanjar getah bening aksila atau bahkan bisa mencapai $5 \mathrm{~cm}$, tetapi belum mencapai kekelenjar getah bening aksila. Perbedaan dai hasil penelitian ini dikarenakan penyajian data adalah tracendy central, sehingga membedakan hasil dengan penelitian lain dalam penyajian distribusi frekuensi(16).

Hasil penelitian ini didapatkan bahwa responden rata-rata pada siklus kemoterapi yang ke 6. Sesuai dengan penelitian Sinaga, Hasibuan, dan Setia pada tahun 2015, mengatakan prinsip kemoterapi melalui pemberian sitostatika (infus) yang efektif dengan tingkat toksik yang minimal sampai sedang. Kemoterapi yang diberikan selama beberapa bulan dengan disertai dengan waktu jeda pemulihan(17). Menurut Utami (2012) satu pengobatan kemoterapi umumnya perlu waktu beberapa bulan, tetapi lamanya tergantung banyaknya faktor dan akan berbeda-beda setiap pasien. Pada pasien yang pertama kali menjalani kemoterapi pasti memiliki persepsi atau penilaian yang jelek terhadap pengobatan yang dijalani, setelah beberapa kali menjalani kemoterapi persepsi atau penilaian pasien pasti akan berubah menjadi lebih baik, karena sudah mengetahui dengan baik tentang efek samping kemoterapi(18). 
Tabel 3. Distribusi Frekuensi Persepsi tentang Efek Samping Kemoterapi

\begin{tabular}{ccc}
\hline Persepsi & f & \% \\
\hline Positif & 34 & 54.0 \\
\hline negatif & 29 & 46.0 \\
\hline n & 63 & $100 \%$ \\
\hline
\end{tabular}

Dari tabel 3 diatas didapatkan bahwa responden yang memiliki persepsi positif sebanyak 34 orang (54.0\%). Hasil penelitian yang dilakukan dari 63 responden didapatkan bahwa 34 responden (54.0\%) cenderung memiliki persepsi positif terhadap efek samping yang dijalaninya sedangkan dari 29 responden (46.0\%) memiliki persepsi negatif terhadap efek samping yang dijalaninya. Persepsi setiap pasien memiliki respon dan penilaian yang berbeda-beda. (19) Robbins (2002), persepsi positif seseorang itu terjadi karena terdapat kepuasan terhadap apa yang dirasakan dan telah dialaminya. Persepsi pasien terhadap penyakit maupun pengobatan yang dijalaninya mempengaruhi proses keputusan dan kepatuhan terhadap suatu prosedur penatalaksanaan medis tertentu yang akan mempengaruhi harapan hidup jangka pendek dan jangka pendek dari suatu kehidupan individu. Persepsi pasien juga dipengaruhi oleh pengetahuan dan informasi yang diperoleh sehingga bisa menimbulkan persepsi positif dan negatif (20).

Menurut Penelitian yang dilakukan Leite, Amorim, Castro, dan Primo pada tahun 2011 mendapatkan bahwa persepsi positif pasien kanker payudara diikuti dengan keinginan untuk hidup, lebih menerima keadaan penyakit dan kepatuhan terhadap pengobatan yang dijalaninya. Pada penelitian Razaq, Alzahrani, Bustami, Alolah, dan Almutlag (2017), persepsi pasien tentang efek samping kemoterapi adalah positif karena telah memberikan edukasi dan konseling yang tepat tentang efek samping kemoterapi yang dijalani pasien kanker. Hasil penelitian ini, peneliti menarik kesimpulan bahwa mayoritas pasien kanker payudara memiliki persepsi positif terhadap efek samping kemoterapi karena pada siklus kemoterapi yang dijalani pada siklus ke 8 sehingga persepsi pasien terhadap efek samping juga semakin sedikit dan semakin baik, persepsi positif ini juga bisa menjadi motivasi untuk mendapatkan kesembuhan yang diharapkan walaupun ada beberapa efek samping yang dirasakan mengganggu beberapa aktivitas mereka sehari-sehari(21).

Tabel 4 Tendency Central Berdasarkan stadium kanker payudara dan siklus kemoterapi

\begin{tabular}{cccc}
\hline Variabel & mean & SD & Min-Maks \\
\hline $\begin{array}{c}\text { Kualitas } \\
\text { Hidup }\end{array}$ & 73.29 & 11,624 & $45-95$ \\
\hline
\end{tabular}

Tabel 4 didapatkan bahwa rata-rata skor kualitas hidup pasien kanker payudara adalah 73.29. Berdasarkan hasil penelitian yang didapatkan bahwa skor rata-rata kualitas hidupnya pada pasien kanker payudara di RSUD Arifin Achmad Provinsi Riau yaitu 73.29 dengan nilai standar deviasi 11,624. Menurut teori Raudhatusalamah (2012) kualitas hidup merupakan suatu pandangan seseorang terhadap kesejahteraan fisik dan psikologis dalam proses peran dan fungsi fisik serta keadaan tubuh yang berpengaruh pada kesehatan dan kesejahteraan umum(12). Menurut teori Walters pada tahun 2009 mengatakan bahwa fungsi dari pengukuran skor kualitas hidup pasien lain memudahkan tenaga kesehatan untuk berkomunikasi dengan pasien, mencari informasi yang mempengaruhi kesembuhan pasien, serta memperbaiki proses penyembuhan pasien dimulai dari membuat keputusan untuk pengobatan, serta sebagai evaluasi keadaan pasien(22). Menurut penelitian yang dilakukan Agustini, Surahman, dan Abdulah pada tahun 2015 mendapatkan bahwa skor kualitas hidup dengan nilai rata-rataa 9,31 dengan standar deviasi 2,34 pada kesehatan umum pasien kanker payudara. Pengukuran pada kualitas hidup ini penting karena bisa mempengaruhi kepatuhan pasien dalam menjalani proses pengobatan kemoterapi(23).

Penelitian Putri (2017) didapatkan bahwa nilai rata-rata kualitas hidup pasien 
yang menjalani kemoterapi yaitu 67,55. Penilaian skor kualitas hidup ini mendapatkan hasil bahwa tidak hanya mengetahui cara mengatasi gejala kanker secara optimal tetapi juga bisa menjadi informasi tambahan untuk mengevaluasi dari hasil pengobatan yang dijalani(24). Penelitian dengan metode analisis wawancara kepada 6 orang, mendapatkan 3 orang menyatakan tentang kualitas hidup bahwa kehidupan ini menjadi bergairah setelah satu minggu kemoterapi. Dalam satu mingu setelah kemoterapi merasakan kelelahan akibat efek kemoterapi(25). Berdasarkan hasil penelitian, peneliti mendapatkan kesimpulan bahwa bagi pasien kanker payudara, kualitas hidup merupakan hal yang penting dalam masa pengobatan serta mampu meningkatkan kepatuhan mereka akan perawatan dan pengobatan serta mampu memberikan antisipasi untuk mengatasi gejala-gejala atau keluhan dirasakan. Kualitas hidup pasien yang bagus karena persepsi pasien rata-rata positif karena siklus yang dijalani sudah mencapai siklus ke 8 yang telah mengubah penilaian pasien yang biasa aja terhadap pasien kanker payudara.

Tabel 5 Hubungan Persepsi tentang Efek Samping Kemoterapi dengan Kualitas Hidup Pasien Kanker Payudara

\begin{tabular}{lcccc}
\hline & Persepsi & Mean & SD & Pvalue \\
\hline $\begin{array}{l}\text { Kualitas } \\
\text { Hidup }\end{array}$ & Positif & 74.97 & 11.72 & 0.216 \\
\hline & Negatif & 71.31 & 11.38 & \\
\hline
\end{tabular}

Berdasarkan tabel 4.7 diatas menunjukkan bahwa pasien dengan persepsi positif rata-rata memiliki kualitas hidup yaitu 74.97 dengan Pvalue $=0.216$ yang diartinya tidak ada terdapat hubungan persepsi tentang efek samping kemoterapi dengan kualitas hidup passion kanker payudara di RSUD Arifin Achmad Provinsi Riau. Berdasarkan hasil uji statistik, melalui uji Independent-Sample $\mathrm{T}$ test didapatkan hasil bahwa tidak terdapat hubungan yang signifikan antara persepi tentang efek samping kemoterapi dengan kualitas hidup pasien kanker payudara $(\mathrm{p}=0.216)$. Hal ini berarti persepsi tentang efek samping kemoterapi tidak mempengaruhi kualitas hidup pasien kanker payudara.

Hasil penelitian ini bertolak belakang dengan penelitian yang dilakukan oleh Gurung dan Pandey pada tahun 2015, menyatakan bahwa persepsi tentang efek samping kemoterapi terbagi menjadi 2 yaitu fisik dan psikologis. Pada efek samping psikologis yang mempengaruhi hubungan keluarga, mempengaruhi hubungan pasangan dan mempengaruhi aktivitas sosial dianggap paling mengganggu dan mempengaruhi kualitas hidup(8). Perbedaan dari penelitian ini karena pada penelitian yang dilakukan Gurung dan Pandey dilakukan pada semua pasien kanker payudara, sedangkan penelitian ini hnya dilakukan pada pasien kanker payudara. Pada penelitian Gurung dan Pandey, responden terbanyak dalam rentang usia 4064 tahun, sedangkan penelitian ini, responden dalam rentang 35-45 tahun.

Menurut teori Diananda pada tahun 2007, pasien yang menjalani kemoterapi dapat mengalami berbagai efek samping kemoterapi tersebut, baik secara fisik dan psikis. Secara klinis, efek samping kemoterapi yang dialami pasien kanker payudara pada kesehatan umumnya baik, merasa nyaman, tidak ada keluhan yang berarti serta kualitas hidupnya baik. Tetapi jika pasien mengalami efek samping dalam keadaan umum tidak baik dan memiliki keluhan yang berarti, maka akan mempengaruhi kualitas hidup pasien(26).

Hasil penelitian ini, peneliti mengasumsikan bahwa hasil penelitian ini berbeda dapat disebabkan oleh pengalaman yang dialami oleh pasien, karena terbiasa menerima kemoterapi yang dijalaninya, dilihat dari tahapan siklus kemoterapi yang dijalani yaitu siklus ke 6. Pasiennya sudah sering terpapar dengan efek samping kemoterapi dan dapat menerima efek samping kemoterapi, sehingga pasien dapat mengatasinya dan tidak mempengaruhi kualitas hidupnya.

\section{KESIMPULAN DAN SARAN}

Berdasarkan penelitian yang telah dilakukan mengenai hubungan persepsi tentang efek samping kemoterapi dengan kualitas hidup pasien kanker payudara 
diwilayah RSUD Arifin Achmad yang dilakukan pada tanggal 29 Mei 2019 terhadap 63 responden didapatkan hasil bahwa banyak responden dalam rentang usia 3145 tahun (dewasa akhir), stadium kanker pasien ratarata yaitu stadium 2 dengan siklus kemoterapi yaitu sikus ke-6. Sebagian besar responden yang memiliki persepsi positif tentang efek samping kemoterapi ratarata skor kualitas hidup yaitu 74.97, dan tidak ada hubungan yang signifikan antara persepsi tentang efek samping kemoterapi dengan kualitas hidup pasien kanker payudara di RSUD Arifin Achmad Provinsi Riau.

\section{REFERENSI :}

1. Olfah, Y., Mendri, N. K., \& Badi'ah, A. Kanker payudara \& sadari. Yogyakarta. Nuha Medika. 2013.

2. Mulyani, N. S., \& Nuryani. Kanker payudara dan PMS pada kehamilan. Yogyakarta. Nuha Medika. 2013.

3. Khamidah, A. N. (2008). Gambaran Stigma pada Paisen Kanker Payudara di RSUD Arifin Achmad Provinsi Riau. Skripsi tidak dipublikasikan.

4. Rekam Medis RSUD Arifin Achamd Provinsi Riau. 2018.

5. Rasjidi, I. (2007). Kemoterapi Ginekologi dalam Praktek Sehari-hari. Jakarta. CV. Sagung Seto

6. Black, J.M., \& Hawks, J.H. (2014). Keperawatan Medikal Bedah: Manajemen Klinis untuk hasil yang diharapkan. Jakarta: Salemba Medika

7. Smeltzer, S.C., \& Bare, B.G. (2002). Buku Ajar Keperawatan Bedah. Jakarta: EGC

8. Gurung, S., Pandey, R. A. Perception of Side Effects Of Chemotherapy Among Cancer Patients in B.P. Koira Memorial Cancer Hospital Bharatpur, Nepal. Journal Of cpllege of Medical Sciences - Nepal. 2015;11(4):14-19. DOI: http://dx.doi.org/10.3126/jcmsn.v11i4.14319.

9. Faisel, C. T. W. Gambaran Efek Samping Kemoterapi Berbasis Antasiklin pada Kanker Payudara di RSUD Dokter Soedarso Pontianak. Skripsi tidak dipublikasikan. 2012.

10. Wahyudi, D., Huda, N., \& Utami, G. T. Studi fenomenologi: pengalaman pasien kanker stadium lanjut yang menjalani kemoterapi. Universitas Riau. 2015;2(2):1041-1047. https://www.neliti.com/id/publications/183589 /studifenomenologi-pengalaman-pasienkanker-stadium-lanjut-yang-menjalanikemote

11. Pieter, H. Z. \& Lubis, Dr. N. L. (2012). Pengantar Psikologis dalam Keperawatan. Jakarta: Prenada Media Group

12. Raudhatussalam. (2012). Psikologi Kesehatan. Pekanbaru: Al-Mujtahad Press

13. Wulandari, N., Bahar, H., Ismail, C.S. Gambaran kualitas hidup pada penderita kanker payudara di Rumah Sakit Umum Bahteramas Provinsi Sulawesi Tenggara. JIMKESMAS, Jurnal Ilmiah Masiswa Kesehatan Masyarakat. 2017;2(6):1-9. https://www.neliti.com/id/publications/183119 /gambarankualitas-hidup-pada-penderitakanker-payudara-di-rumah-sakit-umum-bahte.

14. Rochmawati, D. (2015). Kualitas Hidup Pasien Ca Mamae yang Menjalaani Kemoterapi Terhadap Tingkat Kecemasan pada Pasien Kanker Payudara di RSUD Ibnu Sina. Skripsi tidak dipublikasikan

15. Sirait, A., Oetmiati, R., Indrawati, L. Hubungan Kontrasepsi Pil dengan Tumor atau Kanker Payudara di Indonesia. Majalah Kedokteran Indonesia. 2009;59 (8):348-356. http://dx.doi.prg/10.20473/JPK.

16. Nugraha, S., Melati. R. N. Hubungan Depresi dengan Kualitas Hidup Pasien Kanker yang Menjalani Kemoterapi di RSUD dr. Zainoel Abidin Banda Aceh. Jurnal Ilmiah Terapan. 2016;2(1):1-6. http://jim.unsyiah.ac.id.

17. Sinaga, S. Hasibuan, J. Setia, R. Hubungan Frekuensi Kemoterapi Terhadap Tingkat Kecemasan pada Pasien Kanker Payudara di RSUD Ibnu Sina. Skripsi tidak dipublukasikan. 2015.

18. Utami, S. (2012). Aku Sembuh dari Kanker Payudara, mendeteksi gejalaa dini, pencegahan dan pengobatan. Jakrta: Oryza

19. Robbins, SP. (2002). Prilaku Organisasi. Jakarta: Salemba Medika

20. Robbert, F.S. (2012). Pengantar Psikologi. Jakarta: Salemba Humanika 
21. Leite, F. M. C., Amorim, M. H. C., Castro, D. S. D., Primo, C. C. Coping Strategies and the Relationship with Sociodemographic Conditions of Womwn with Breast Cancer. Original Article. 2012;25(2):211-217. http://dx.doi.org/10.1590/So103.21002012000 200009.

22. Walters, S.J. Quality of Life Outcomes in Clinical Trials and Healt-Care Evaluation: Practical Quide to Analysis and Interpretation. America: Willeys and Son. 2009.

23. Agustini, D.D., Surahman, E., Abdullah, R. Kualitas Hidup Pasien Kanker Payudara dengan Terapi Kombinasi Fluorouracil, Doxorubicin, dan Cyclofosfamide. Jurnal Farmasi Klinik Indonesia. 2015;4(3):175-185. DOI:10.15416/ijcp.2015.4.3.175.

24. Putri, R. H. (2017). Kualitas Hidup Pasien Kanker Ginekologi yang Menjalani Terapi. Aisyah: Jurnal Ilmu Kesehatan. 2(1), 69-72. http://ejournal.stikesaisyah.ac.id/index.php/eja

25. Ladjar, Sr. I. I. Kualitas Hidup Pasien Kanker yang Menjalani Kemoterapi di Ruang Edelweis RSUD Banjarmasin Tahun 2015. Socioscientia: Jurnal Ilmuilmu Sosial. 2016;8 (1):137-142. https://lldikti11.ristekdikti.go.id.

26. Diananda, R. Mengenal Seluk Beluk Kanker. Yogyakarta. Katahati. 2007. 